\title{
Evaluation Of The Effect Of Pre-Treatment Of Moringa Oleifera Lamarck (Moringaceae) Seeds At The Early Stage Of Germination For Massive Production In South Benin
}

\author{
Pascal Gbenou \\ Research Unit in Plant Biotechnology, Crop Protection and Seed Sciences; \\ Plant, Horticultural and Forest Sciences Laboratory; School of Plant and \\ Seed Management and Production (EGPVS); \\ National University of Agriculture (UNA),Bénin, \\ Farm-School SAIN, Laboratory of Rural Geography and Agricultural \\ Expertise (LaGREA) / University of Abomey-Calavi / Benin

\section{David Hombada}

Research Unit in Plant Biotechnology, Crop Protection and Seed Sciences;

Plant, Horticultural and Forest Sciences Laboratory; School of Plant and

Seed Management and Production (EGPVS);

National University of Agriculture (UNA),Bénin

David Romaric Nevis

2Farm-School SAIN, Laboratory of Rural Geography and Agricultural

Expertise (LaGREA), University of Abomey-Calavi, Benin

\section{Doi:10.19044/esj.2021.v17n3p165}

Submitted: 16 June 2020

Accepted: 26 October 2020

Published: 31 January 2021
Copyright 2021 Author(s)

Under Creative Commons BY-NC-ND

4.0 OPEN ACCESS

Cite As:

Gbenou P., Hombada D. \& Romaric Nevis D. (2021). Evaluation Of The Effect Of PreTreatment Of Moringa Oleifera Lamarck (Moringaceae) Seeds At The Early Stage Of Germination For Massive Production In South Benin. European Scientific Journal, ESJ, 17(3), 165.

https://doi.org/10.19044/esj.2021.v17n3p165

\section{Abstract}

Moringa Oleifera Lam., a tropical tree with multiple uses, used as a vegetable, is part of the eating habits of rural and urban communities. This study, which took place in the city of Cotonou, aims to contribute to a massive production of Moringa plants with a view to its promotion. In this line, an experimental protocol has been set down. Thus, four types of seed pretreatments were tested on a nursery whose plants are randomly arranged in four blocks of 30 plants with four repetitions. The treatments consisted of a 
control (seeds not pretreated) of seeds pre-heated to $50^{\circ} \mathrm{C}$, seeds soaked for 48 hours in water and scarified seeds. The variables measured are the speed of germination, the height of the plants, the length of the stems and the number of leaves.. The results obtained show that the germination time is significantly better already from the 5th day after sowing for the heated seeds with a germination rate of $74.16 \%$. As for scarified and soaked seeds, the germination rate is low $42.5 \%$. However, at the development stage, the scarified seeds have a better stem height from the 50th day after sowing, a significant difference is observed between the controls $(44,52)$; scarified $(48.66)$ and seeds heated to $45^{\circ} \mathrm{C}(41.38)$ and a similar difference between controls (44.52) and soaked $48 \mathrm{~h}$ (43.28). the same result is obtained for the length of the leaves from the 20th day after sowing or there is a significant difference $(\mathrm{P}=0.0228)$ between the plants of the batches of scarified seeds and the seeds soaked for 48 hours and a similar difference between the soaked for 48 hours and the seedlings heated $(6,17)$. On the other hand, the number of sheets parameter does not vary considerably depending on the pre-treatments. At the start of the experiment, a significant difference $(\mathrm{P}=0.0011)$ was observed between the plants whose seeds were heated (3.43) and the soaked 48h (3.00) and the controls (2.57) and scarified (2.97). Decision makers must take steps to make Moringa Oleifera accessible to all populations through the creation of plantations for exploitation.

Keywords: Moringa Oleifera, Nursery, Seed Treatment, Mass Production, Cotonou

\section{Introduction}

Moringa Oléifera is a plant species native to northern India and is now acclimatized in almost all tropical regions. It is a shrub up to 10 meters tall and belongs to the Moringaceae family (Makker et al.; 1997 et Arbonnier, 2000). Moringa Oléifera is described as a "tree of life", a "miracle tree" or a "divine plant" because of its many nutritional, medicinal and industrial potentials (Fulgie, 2001 et Olson, 2001).

Moringa Oléifera can be found in very arid areas like the Sahara, but it prefers humid semi-tropical climates (FAO, 2008 et Broin, 2010) and can adapt to any type of soil but adapts better to the hills and the borders of rivers( Palou et al.; 2011). It reproduces easily by seeds and by cuttings. It can be cultivated intensively irrigated for optimal production of leaves in order to harvest them every six weeks (Palada et al.; 2009). It can also be grown in house culture or in an intercropping system (Palou et al.; 2011)

However, the interest given to this tree by many researchers in tropical countries where malnutrition is legion is due to these many qualities and virtues. Indeed, it has been proved by [9] that practically all the parts of 
Moringa Oléifera are used according to their contents in oil, in polypeptides and in growth factors.

Studies have shown that fresh leaf juice can increase yields by $25-30 \%$ for many crops (Foidl, 2001; fuglie 2001; Basra et al.; 2009, Makker et al.; 2010).

In Benin, the popularization of Moringa Oléifera started faintly since 1997. It was from 2002; that the 'Peace Corps Benin' 'supported with (Ogoudadja et al.; 2006) the NGO Garpe gave a boost to the marketing of Moringa Oléifera plants. The fact is that the production of fruit vegetables in southwest Benin does not seem sufficient to meet the demand of the population. This is due to a small amount produced by market gardeners. However, Moringa Oléifera appears to be a solution to alleviate the huge evils from which the Beninese population suffers (Adjatin, 2006; Hedji et al.; 2014). They must crash into this plant to better use it. The access to this plant and its leaves remain respectively more and more difficult and rare on our markets despite the efforts of research structures, non-governmental, national and international organizations for the popularization of this plant in Benin. As the multiplication of a plant depends on its germination capacity, the study of the effect of a few pretreatments germination in the southwest of Benin, an area where the climate is different from that of the North is very importante. The ultimate goal will be to facilitate its popularization in the area for its multiple virtues.

\section{Materials and methods \\ Presentation of the study area}

The study area covers the southwest part of Cotonou in the Littoral department. The climate is subequatorial with an alternation of two rainy seasons (from April to July and September to November) and two dry seasons (from December to March and August). The pluviometry varies between 900 and $1200 \mathrm{~mm}$, while the average temperature is around $27^{\circ} \mathrm{C}$ with a maritime influence (Boko et Adam, 1994). The soil is sandy and poor in organic matter with a low exchange capacity and a low water retention capacity. The vegetation is sparse and scattered, consisting mainly of halophytes (Boko et Adam, 1994). Agricultural activities are reduced to market gardening (Figure $1)$.

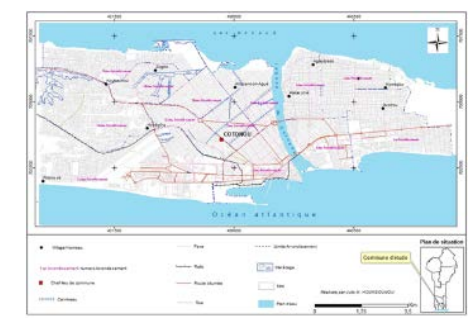

Figure 1. Situation map of the study area 


\section{Plant material}

The plant material consists of Moringa Oléifera plants obtained in the nursery. Moringa Oléifera seeds obtained from the NGO "wake up" were subjected to three different types of pretreatment. The first was heating the seeds to $50^{\circ} \mathrm{C}$, then comes the scarification and the third soaking in cold water for 48 hours. A fourth group of seeds did not undergo any pretreatment and was considered as a control (Photo 1).

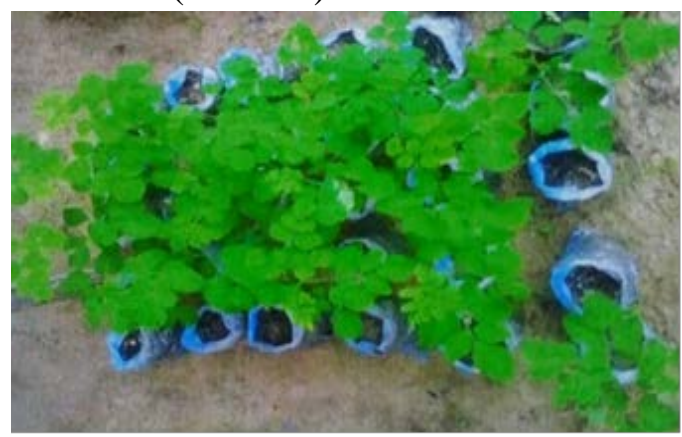

Photo 1. Moringa Oléifera plants

\section{Experimental protocol}

A nursery measuring $5 \mathrm{~m}$ out of five has been set up to shelter plots of 20 pots repeated four times for each treatment according to the experimental plan. The sieved potting soil was brought to the site few days before sowing; then the bag of potting soil was made in the shade of a tree during the day. A straw shade house has been built on the site. One seed from each group of pretreated seeds was sown on each plot (consisting of 30 sachets) separately. Moringa Oléifera seeds were put in the nursery after scarification, heating to $50^{\circ} \mathrm{C}$ and soaking for 48 hours; some of the seeds were also put in the nursery without pretreatment and considered as a control. The first two treatments were carried out during the day, however the soaked seeds remained in the shade for 48 hours. Every morning the beds were abundantly watered to capacity in the field. A total of 480 seeds of M. Oléifera were used for the experiment. Every morning, the boards were abundantly watered to capacity in the field. Data on seed germination was collected every ten days. They relate to the time of trick (date of the seed trick after sowing), the number of seeds lifted per treatment, the average height of the plants, the length of the leaves, and the number of leaves. The data were collected over 2 months using a measuring tape and a graduated measuring ruler (Photo 2). 


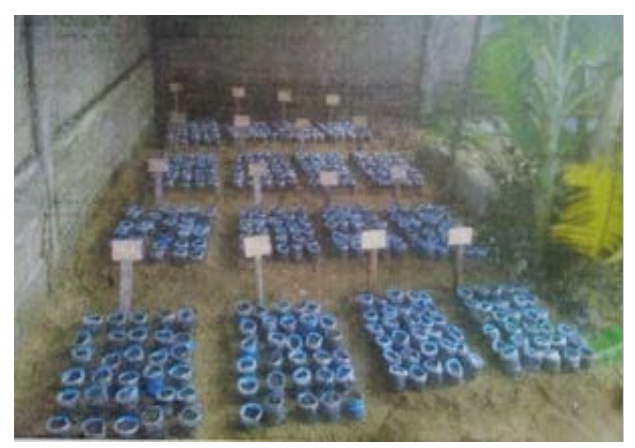

Photo 2. Experimental device

\section{Data processing and analysis}

Data collection took place on the germination of Moringa Oleifera seeds in the nursery under the effect of some treatments. The variables are: the height of the stems; the number of sheets; the length of the leaves and the speed of germination. Here, the Excel spreadsheet was used for entering and recording the collected data. This spreadsheet made it possible to transform the data in a histogram form or in tabular matter. The data relating to the average height of the plants, the length of the leaves, the number of leaves and the speed of germination as a function of time were subject of the analysis of a variance (ANOVA) with the STATITIX 8 software. The test LDS made it possible to compare the average and structure them into different classes. The results of the analysis were presented in tabular matter.

\section{Results}

\section{Average seed germination rate}

The experiment results reveal a very high germination rate in seeds heated to $50^{\circ} \mathrm{C}(74.16 \%)$ followed by controls (51.66\%). As for the scarified and soaked seeds, the germination rate is low with (42.5\%). The germination time is 3 days for pre-treated seeds and 4 days for controls. It can therefore be said that the pretreatment of the seeds has a positive effect on the percentage of germinated heating seeds in particular, and also on the germination time (Table 1).

Table 1. Average germination rate per treatment

\begin{tabular}{|c|c|}
\hline Treatment & Average germination rate \\
\hline witness & $51,66 \%$ \\
\hline scarified & $42,5 \%$ \\
\hline soaked 48h & $42,5 \%$ \\
\hline heated & $74,16 \%$ \\
\hline
\end{tabular}

Source: Experimental results, 2019 


\section{Evaluation of the growth parameters of Moringa Oléifera plants}

The results of the analysis of variance (ANOVA) for the stem height parameters, leaf length and number of leaves are summarized in tables 2, 3 and 4. It appears from table 2 that there is a significant difference from the 10th day after sowing between the soaked 48 hours (8.74) controls (11.59) and scarified seeds (9.98). There are no significant differences between scarified $(9,98)$ and seeds heated to $50^{\circ} \mathrm{C}(10,25)$. There is no significant difference from the 20th JAS to the 40th JAS. On the other hand, a significant difference is observed between the controls (44.52), the scarified ones (48.66) and the seeds heated to $45^{\circ} \mathrm{C}$ (41.38) from the 50th JAS. A similar difference is observed between the controls (44.52) and the 48-hour soaks (43.28). This means that from the pretreatment effect of the seeds, the scarification is favorable to the stems parameter from the 50th JAS. Table 3 shows that for the leaf length parameter, a significant difference $(\mathrm{P}=0.0021)$ at the 10th JAS between the 48h soaking and the controls; no significant difference between the scarified (4.05), and the heated seeds (4.22) and the controls (4.34). On the other hand, there is a significant difference $(\mathrm{P}=0.0228)$ between the plants of the batches of scarified seeds and the seeds soaked for 48 hours from the 20th JAS. However, a similar difference is observed between $48 \mathrm{~h}$ soaking and heated seedlings $(6,17)$. At the 30th JAS, there is a similar difference between the 48-hour soaking and the controls and a significant difference between the seedlings of the scarified seeds and the controls. At the 40th JAS, a significant difference is observed between the seedlings of the scarified seeds (7.56) and those soaked for 48 hours (7.00) and the seedlings of the heated seeds (6.79) and the controls (7.33). We observe in the 50th JAS the same trends observed in the 30th JAS. It therefore follows that the pretreatment of the seeds, in particular scarification has a positive effect on the parameter length of the leaves during our experiment compared to the batches of controls. Table 8 presents the results of the variation in the number of leaves per plant. A significant difference is observed at the begining of the experiment $(\mathrm{P}=$ 0.0011 ) between the plants whose seeds have been heated (3.43), the soaked for 48 hours (3.00), the controls (2.57), the scarified ones (2,97). However, no significant difference was observed in the rest of the experiment. We therefore conclude that the seed pretreatment effect has no significant impact on the number of leaves parameter.

Table 2. The results analysis of the height $(\mathrm{cm})$ parameter of the Moringa Oleifera stems depending on the treatments

\begin{tabular}{|c|c|c|c|c|c|}
\hline JAS & \multicolumn{2}{|c|}{ TREATMENTS } & P \\
\hline & Witness & Scarified & Soaked 48h & Heated $45^{\circ} \mathrm{C}$ & \\
\hline $\mathbf{1 0}$ & $11,59 \mathrm{~A}$ & $9,98 \mathrm{AB}$ & $8,74 \mathrm{~B}$ & $10,25 \mathrm{AB}$ & 0,1131 \\
\hline $\mathbf{2 0}$ & $20,36 \mathrm{~A}$ & $19,65 \mathrm{~A}$ & $18,99 \mathrm{~A}$ & $17,04 \mathrm{~A}$ & 0,5492 \\
\hline $\mathbf{3 0}$ & $26,61 \mathrm{~A}$ & $26,65 \mathrm{~A}$ & $26,56 \mathrm{~A}$ & $26,06 \mathrm{~A}$ & 0,9899 \\
\hline
\end{tabular}




\begin{tabular}{|l|c|c|c|c|c|}
\hline $\mathbf{4 0}$ & $35,54 \mathrm{~A}$ & $47,41 \mathrm{~A}$ & $35,33 \mathrm{~A}$ & $33,16 \mathrm{~A}$ & 0,2553 \\
\hline $\mathbf{5 0}$ & $44,52 \mathrm{AB}$ & $48,66 \mathrm{~A}$ & $43,28 \mathrm{AB}$ & $41,38 \mathrm{~B}$ & 0,1303 \\
\hline
\end{tabular}

Source: Experimental results, 2019

JAS = number of days after sowing, the averages in the rows bearing the same letters are not significantly different at the $5 \%$ threshold

Table 3. The results analysis of the length $(\mathrm{cm})$ parameter of the Moringa Oleifera leaves according to the treatments

\begin{tabular}{|c|c|c|c|c|c|c|}
\hline JAS & \multicolumn{4}{|c|}{ TRAITEMENTS } & \multirow[t]{2}{*}{ LSD } & \multirow[t]{2}{*}{$\mathbf{p}$} \\
\hline & Witness & Scarified & Soaked $48 \mathrm{~h}$ & Heated $45^{\circ} \mathrm{C}$ & & \\
\hline 10 & $4,34 \mathrm{~A}$ & $4,05 \mathrm{~A}$ & $2,96 \mathrm{~B}$ & $4,22 \mathrm{~A}$ & 0,2982 & 0,0021 \\
\hline 20 & $6,58 \mathrm{AB}$ & $6,86 \mathrm{~A}$ & $6,32 B$ & $6,17 \mathrm{~B}$ & 0,1986 & 0,0228 \\
\hline 30 & $6,98 \mathrm{AB}$ & $7,27 \mathrm{~A}$ & $6,84 \mathrm{AB}$ & $6,55 B$ & 0,243 & 0,0739 \\
\hline 40 & $7,33 \mathrm{AB}$ & $7,56 \mathrm{~A}$ & $7,00 \mathrm{BC}$ & $6,79 \mathrm{C}$ & 0,1967 & 0,0093 \\
\hline 50 & $7,58 \mathrm{AB}$ & $7,78 \mathrm{~A}$ & $7,65 \mathrm{AB}$ & $7,24 \mathrm{~B}$ & 0,1925 & 0,0827 \\
\hline
\end{tabular}

Source: Experimental results, 2019

JAS = number of days after sowing, the averages in the rows bearing the same letters are not significantly different at the $5 \%$ threshold

Table 4. The results analysis for the number of leaves parameter of Moringa Oleifera according to the treatments

\begin{tabular}{|c|c|c|c|c|c|}
\hline JAS & \multicolumn{4}{|c|}{ TREATMENTS } & \multirow[t]{2}{*}{$\mathbf{P}$} \\
\hline & Witness & Scarified & Soaked $48 \mathrm{~h}$ & Heated $45^{\circ} \mathrm{C}$ & \\
\hline 10 & 2,97B & 2,97B & $3,00 \mathrm{~A}$ & $3,43 \mathrm{~A}$ & 0,0011 \\
\hline 20 & $6,04 \mathrm{~A}$ & $6,04 \mathrm{~A}$ & $6,00 \mathrm{~B}$ & $6,00 \mathrm{~B}$ & 0,1678 \\
\hline 30 & $7,26 \mathrm{~B}$ & $7,62 \mathrm{~A}$ & $7,58 \mathrm{~B}$ & $7,64 \mathrm{~A}$ & 0,1814 \\
\hline 40 & $9,28 \mathrm{~A}$ & $9,41 \mathrm{~A}$ & 9,37A & 9,37A & 0,9549 \\
\hline 50 & $11,31 \mathrm{~A}$ & $11,37 \mathrm{~A}$ & $11,28 \mathrm{~A}$ & $11,08 \mathrm{~A}$ & 0,7464 \\
\hline
\end{tabular}

Source: Experimental results, 2019

JAS = number of days after sowing, the averages in the rows bearing the same letters are not significantly different at the $5 \%$ threshold

\section{Discussion}

The current study has shown that the germination rate is quite high for Moringa Oléifera seeds preheated to $45^{\circ} \mathrm{C}(74.16 \%$.) according to (Pamo, et al.; 2004). Heating the seeds significantly accelerates the speed of germination. It is also an effective way to soften the seed coat and therefore reduce its impermeability to water. In addition, according to (Robertson et al.; 1997, Moussa et al.; 1998), the heating of seeds allows the revival of the metabolic activity of the seed and therefore the development of the embryo. On the other hand, the low percentage of germination observed in pre-soaked and scarified seeds would be due to the exposure of the embryos to rots and to attacks by parasites. Indeed after soaking the seeds for 48 hours, the solution containing the seeds is very heavy and thick. This phenomenon can be explained by a probable diffusion of the sugars and proteins contained in the 
seed in the water. The results on the germination rates are different from those obtained by the work of (Njehoya et al.; 2014) in the Sudano-Guinean zone of Cameroon. Indeed, the latter obtain a rate of $96 \%$ for scarified seeds. This variation in rates could be related to the differences observed between the origins of the seeds. These authors in their works have proven a correlation between the origin of the seeds and their germination rates. As part of our experiment, the pre-treated seeds germinated faster than the control seeds (1 day less than the controls). This result is therefore supported by the assertion of Sohdi and Harris cited by (Bourou, 2004) in Senegal on two local varieties of cowpea (Vigna unguiculata). According to these authors, the difference in germination time of the pre-soaked seeds and the control seeds is 1 to 3 days. The germination time of Moringa Oléifera seeds is 12 days (Gamate, 2006). But during our experimentation, the germination time was 4 days for untreated seeds. The time for germination of Moringa Oléifera seeds is therefore between 3-12 days. However, the trend changes during the plant development phase so that the growth of plants from heated seeds slows down compared to control batches. This trend can be explained by the fact that the heating of the seeds does not allow the growth hormone to quickly activate. On the other hand, the scarification allows better development of stems and leaves (Fakeye, 2008). The development of seedlings from scarified seeds could be due to the rapid use of seed reserves and which favored growth. These results are consistent with those obtained by (Abdellaoui, 2014) who showed that scarification has activated the development and growth of young seedlings for two species of Hédysarum. The latter claims that scarification did not harm the development of seedlings. For rapid germination, pre-treatment of seeds is therefore essential. We obtained plants of $70 \mathrm{~cm}$ height in 50 days. thanks to the pre-treatment.

\section{Conclusion and suggestions}

It results from this study that the scarified seeds have a low germination rate $(42.5 \%)$ but develop faster. Seeds heated to $45^{\circ} \mathrm{C}$ have a high germination rate $(74.16 \%)$ and slow growth. Witnesses behave better than seeds soaked for 48 hours. On the one hand, these results will allow nurserymen to reduce the duration of germination and at the same time obtain very high germination rates and therefore a significant biomass.

Thus, the following suggestions have been made in order to have a deeper and broader knowledge of the potential of Moringa Oléifera:

- Consider studies to better understand the impact of seed storage conditions on the germination of Moringa. Oléifera;

- Develop efficient intensive and semi-intensive cultivation systems and cultural practices that respect the environment in Benin;

- Repeat the same tests in the agro-ecological conditions of North Benin; 
- Repeat the tests and this with other pre-treatment methods.

\section{References:}

1. Makkar, H.P.S. et Becker, K., 1997. Nutrients and antiquality factors in différent morphological parts of the Moringa Oléiferatree. Journal of Agricultural Science, Cambridge 128,311322.

2. Arbonnier M, 2000. Arbres, Arbustes et lianes des zones sèches d'Afrique de l'Ouest. CIRAD-MNHN-UICN, p. 417

3. Fuglie, Lowell J., 2001. Combattre la malnutrition avec le Moringa in l'arbre de la vie, les multiples usages du Moringa. CTA et CWS Dakar, pp. 119 à 139

4. Olson M.E., 2001. Introduction to Moringa familly (11-28) in Fuglie L.D (editor). The miracle tree : the multiple attributes of Moringa, wageningen CTA ; Dakar ; cws- p 177.

5. Broin M., 2010. Diagnostic préalable à la sensibilisation. CTAACP-UE. http://www.moringanews.org

6. FAO, 2008. Perspectives agricoles de l'OCDE et de la FAO 20082017, OCDE/FAO, p.83

7. Palou Madi O., Bourou S., Woin N., 2011. Utilisations et importance socio-économiques du Moringa Oleifera ??? au Maroua, Cameroun, Journal of Applied Biosciences 60: 44214432

8. Palada M. C. and Chang L. C., 2009. Suggested culture practices for moringa. International Cooperations'Guide. AVRDCP $\mathrm{N}^{\circ} 03-$ 545. :1-5.

9. Foidl N, Makkar H.P.S. et Becker K., 2001, potentiel de Moringa Oléifera en Agriculture et dans l'industrie, 20pp Acte de conférence Dar Es Salam, Tanzanie

10. Basra SMA, Zahar M, Rehman H, Yasmin A, Munir H, 2009a. Evaluating the response of sorghum and Moringa leaf water extracts on seedlinggrowth in hybridmaize. In : Proceedings of the International conference on Sustainable Food Grain Production : challenges and Opportunities. University of Agriculture, Faisalabad, Pakistan, pp.22.

11. Basra SMA, Zahoor R, Rehman H, Afzal I, Farooq M., 2009b. Response of rootappliedbrassica and Moringa leaf water extracts on seedling growth in sunflower. In : Proceedings of the International conference on Sustainable Food Grain Production :challenges and Opportunities. University of Agriculture, Faisalabad, Pakistan, pp.23. 
12. Ogoudadja D., Saint Sauveur A., 2006. Fiche économique sur la production de poudre de feuilles de Moringa. Cas du Bénin : Production en culture associée par des groupements de femmes (Moringanews).

13. Hedji C. C., Kpogue Gangbazo D.N.S., Houinato M.R., Fiogbe E.D., 2014. Valorisation d'Azollaspp, Moringa Oléifera, son de riz, et de Co produits de volaille et de poisson en alimentation animale J Appl. Bioxi, pp. 13

14. Adjatin A., 2006. contribution à l'étude de la diversité de légumes feuille traditionnel consommés dans le département de l'Atakora au Togo.

15. Agbenoko L., 1991. Moringa Oléifera. L’arbre purificateur. Sylva, Réseau arbres tropicaux. Le flamboyant, 34-35.

16. Adam et Boko, 1994. Géographie du Bénin, EDICEF, p. 96

17. Pamo Tedonkenge E., et al. 2004. Potentiel de germination de Moringa Oléifera LAM sous différents traitements à Dschang dans les hautes terres de l'ouest-Cameroun, journal of Cameroun Academy of science, vol N³ pp 199-2003

18. Robertson BL, Small JGG, 1997. Germination of Jubaeopsiscaffra seeds. Principes $21: 114-122$

19. Moussa H, Margolis HA, Dube PA, Odongo J., 1998. Factors affecting the germination of doum palm (Hyphaenethebaica ; Mart.) seeds from the semi-arid of Niger, West Africa. Forest Ecology and Management 104:27-41.

20. Njehoya C.A., Bourou S., Bouba H., 2014. Evaluation du potentiel de germination de Moringa Oléifera dans la zone soudanoguinéenne du Cameroun. Journal of Applied Biosciences 74 : 6141-61.8, pp8.

21. Bourou S., Braconnier S., 2004. Effet du pré-trempage des graines sur l'évolution de quelques paramètres agro-physiologies de deux variétés locales de NIEBE (Vignaunguiculata) en condition d'alimentation hydrique variées Mémoire présenté pour l'obtention du diplôme d'études Approfondies de biologie végétales 50 pages.

22. Gamate M., 2006. Feuilles de Moringa : stratégie, normes et marchés pour un meilleur impact sur la nutrition en Afrique Atelier international Accra

23. Fakeye H.M., 2008. Etude de faisabilité du développement de la filière Moringa Oléifera, p. 64

24. Ahoton L.E., Adjakpa J.B. ET Akpo E.L., 2009. Effet des prétraitements des semences sur la germination de prosopis africana, p. 6 
25. Abdellaoui Z., 2014. Contribution à l'étude de la germination et des premiers stades de développement de Hedysarumsp. Mémoire pour l'obtention du diplôme universitaire de Magister, p.95 